\title{
A MESSAGE FROM THE VICE PRESIDENT
}

I would like to extend my best wishes for a new year to all members of NALLD. May 1974 be a good and prosperous year for each of you.

This will be the year of challenge for NALLD. Our first challenge is the 1974 Annual Conference, which will be held in Atlantic City, New Jersey, on Tuesday, March 19, 1974. During the Annual Conference, we will be looking for interested persons to assist in the formation of an East regional chapter.

We are forming regional chapters to enable our membership to take an active part in the national association. It should not be necessary for anyone to travel more than $\mathbf{3 7 5}$ miles to a regional meeting. If traveling to our National Conference is too costly, perhaps you will be able to attend your regional meeting. Our California-Nevada chapter, which was a pilot project of NALLD, has shown great promise and good participation since it was formed.

In April, we will hold a regional conference in Milwaukee, Wisconsin, in conjunction with the Central States Conference. At that time, we hope to form another regional chapter.

I urge each and every member to attend our Annual Conference, as I would like to become personally acquainted with each one of you. Only through our combined efforts can we succeed in making NALLD an effective and efficient organization. All the help we can get will be greatly appreciated, and I'm sure it will be equally rewarding to those who participate.

If anyone has any suggestions, I am as close as your mailbox and would enjoying hearing from you. Please feel free to write me anytime (Laboratory Director, Box 3-L, Foreign Language Department, New Mexico State University, Las Cruces, New Mexico 88003).

Hope to see you in Atlantic City for our Annual Conference.

Sincerely yours,

Roy L. Krynitz, Vice-President, NALLD 